\title{
SURVIVALISM, CORRUPTIONISM, AND MEREOLOGY
}

\section{DAVID S. ODERBERG}

University of Reading

\begin{abstract}
Corruptionism is the view that following physical death, the human being ceases to exist (until Resurrection) but their soul persists in the afterlife. Survivalism holds that both the human being and their soul persist in the afterlife, as distinct entities, with the soul constituting the human. Each position has its defenders, most of whom appeal both to metaphysical considerations and to the authority of St Thomas Aquinas. Corruptionists claim that survivalism violates a basic principle of any plausible mereology, while survivalists tend to reject the principle, though without as much detail as one would like. In this paper I examine both the key exegetical issues and the mereological question, arguing (i) that Aquinas cannot be shown to have supported the principle in question, and (ii) that the principle should be rejected on independent grounds. If correct, some key planks in support of survivalism are established, with others to await further examination.
\end{abstract}

\section{INTRODUCTION}

There is a vigorous and fascinating debate currently taking place in philosophy of religion, concerning the nature of immortality. Although both sides are almost without exception followers of, or inspired by, the thought of St Thomas Aquinas, the debate has interest for anyone who either believes in, or wants at least to make sense of, the idea of a life following physical death. Moreover, at least some of the issues that have been aired should be of interest to those with no special regard for Thomistic thought; indeed they have interest beyond philosophy of religion altogether.

Both sides make classical Thomistic assumptions, wholly in line with traditional Christian thought, concerning the immortality of the human soul and its fate of reward, punishment, or purgation following 
a human's physical death. The debated question is the following: does the human being, i.e. human person, survive physical death along with his soul, or is it only his soul that survives his physical death? Following Patrick Toner, the philosopher who has contributed most to the debate and in many ways set its terms, I call those who believe that only the soul survives corruptionists, and those who believe the soul and the person survive survivalists. ${ }^{1}$

One might have thought this question settled long ago by some authority recognized by both sides. Surely, for example, Aquinas made it clear exactly what he thinks, this being just the sort of question he would have been minded to answer - as it were a question made in Heaven for a Christian Aristotelian? Or must it not be that some extra-philosophical source - Church dogma, the practically unanimous teaching of theologians, even Scripture itself - has at least supplied an answer worthy of acceptance by both sides, with only the philosophical mechanics of the correct view, so to speak, left to be worked out? Surprisingly, this seems not to be the case. I have not made an exhaustive search of relevant sources, nor is the matter of extra-philosophical authority something that deserves special attention in a philosophy article. That said, it does seem that the matter of survivalism versus corruptionism is still a wholly open philosophical question. And there is a significant number of philosophers on both sides. ${ }^{2}$

There are at least three major issues at the centre of this ongoing dispute. One is whether Aquinas himself was a survivalist or corruptionist. Corruptionists make a very strong case that Aquinas believed as they do, but my view is that although a compelling case for Aquinas's survivalism is hard to make, he can and should be interpreted in a way that is consistent with survivalism. ${ }^{3}$ Another is whether corruptionism is as

\footnotetext{
${ }^{1}$ See Toner 2009a, 2009b, 2010, 2012. Brown 2005 coined the term 'corruptionist'.

${ }^{2}$ Toner (2012): $n .1$ gives a long list. Apart from being the leading corruptionist himself, there are among others: Kenny (1993): 138; Pasnau (1992): 380ff.; Davies (1992): 215-20. The survivalists include: Stump (2003): 51-4; Brown (2005): 120-4; Hershenov and KochHershenov (2006); Hershenov (2008). All of the corruptionists just listed claim both that corruptionism is correct and that Aquinas held it. The same goes for the survivalists apart from Hershenov (and Koch-Hershenov), who think Aquinas was a corruptionist and wrong about it. In Oderberg (2005) and (2007) I also defend survivalism and attribute the same view to Aquinas.

${ }^{3}$ For the strongest case in favour of a corruptionist reading, see Toner (2009a) and his other articles. Stump (2003) and (2006) offers a plausible reading of Aquinas as survivalist. See also Oderberg (2005).
} 
well equipped as survivalism to account for the deserts that are meted out in the afterlife. ${ }^{4}$ For the survivalist, since the person persists beyond physical death, it is they who are rewarded or punished. The corruptionist has the difficult task of accounting for what seems to be the unfairness of rewarding or punishing one thing (the soul) for what something else (the now non-existent person) did during its earthly life. A third issue is whether survivalism violates a putatively self-evident principle of mereology, called the Weak Supplementation Principle, since it seems to involve the view - assuming, along hylemorphic lines, that a person is not identical to their soul nor could ever become identical to their soul - that following physical death a person continues to exist with only one proper part, namely their soul. It is this third issue that will occupy the remainder of the present paper.

\section{THE WEAK SUPPLEMENTATION PRINCIPLE: SOME BACKGROUND}

Classical extensional mereology (CEM) is generally held to include the Weak Supplementation Principle (WSP) as one of its axioms. ${ }^{5}$ Taken to be one of the minimal requirements of any adequate mereology, the principle states: if $\mathrm{x}$ is a proper part of $\mathrm{y}$ (i.e., any part of $\mathrm{y}$ other than $\mathrm{y}$ itself, y being an 'improper' part of itself), then there is some other proper part $\mathrm{z}$ of $\mathrm{y}$ that does not overlap $\mathrm{x}$, that is, shares no part with $\mathrm{x} .{ }^{6}$ In other words, nothing can have a 'single' proper part in the technical sense of a proper part that is not 'supplemented' by another that is disjoint from it. WSP will evidently be violated if an object has a numerically single proper part. It will also be violated if an object has many disjoint proper parts but also has a proper part that overlaps - shares parts with, is not disjoint from - all of the others. For the part that overlaps all the others will itself exist without a supplement.

Kathrin Koslicki thinks WSP is 'pretheoretically plausible' and 'partially constitutive of the meaning of "is a proper part of"'? Indeed

${ }^{4}$ For the argument that corruptionism has serious problems accounting for the fairness of post-mortem rewards and punishments, see Hershenov and Koch-Hershenov (2006). For a detailed and ingenious response (ultimately unsuccessful, in my view) see Toner (2012).

${ }^{5}$ Simons (1987): 28ff.

${ }^{6}$ No proper part, of course, and no improper part - which would be the case if $\mathrm{x}=\mathrm{y}$.

${ }^{7}$ Koslicki (2008): 183. 
she appeals to WSP in defence of a neo-Aristotelian, hylemorphic theory of material constitution. Since, she argues, an object such as a statue can be constituted by a single lump of clay (a proper part of the statue, i.e. not identical to it) that has no other disjoint material parts, there must be a formal part (its structure) to supplement the lump, giving the statue two constitutive and non-overlapping parts. For Effingham and Robson, 'denying WSP is not a credible option' since it is 'not only eminently plausible and in accord with our intuitions, but it is also an axiom of just about every mereology available. ${ }^{8}$ Casati and Varzi note sympathetically that '[s]ome authors (most notably Peter Simons) regard [WSP] as constitutive of the meaning of "part" and would accordingly list it along with the lexical postulates of mereology."

Not everyone shares this intuition concerning WSP. Maureen Donnelly, in the course of a detailed examination of the role of WSP in Koslicki's theory, writes: 'I myself have no intuitions whatsoever regarding the truth or falsity of (WSP). ${ }^{10}$ She thinks the idea that WSP is in accord with general intuitions about parthood has not been shown to have any empirical support, and that there is no conception of parthood in general such that non-philosophers (or for that matter philosophers, since not all accept the principle) could appeal to it in defence of the idea that weak supplementation just is one aspect of what it is to be a part of anything whatsoever. Donald Smith expresses himself even more strongly, taking WSP to be plain false. ${ }^{11}$ Effingham and Robson, to whom Smith is replying, propose the idea of a multiply located, time-travelling brick that composes an entire wall, arguing that the scenario requires fourdimensionalism in order to bring it into line with WSP. (No single brick, without supplementation, can compose an entire wall - only distinct, disjoint temporal parts can do so.) Smith, by contrast, denies the need for a four-dimensionalist interpretation, arguing that the scenario, bizarre though it may be, demonstrates the falsity of WSP. Indeed, the atypical nature of the thought experiment shows, for Smith, that WSP is routinely accepted by mereologists - and by non-philosophers who understandably

${ }^{8}$ Effingham and Robson (2007): 635.

${ }^{9}$ Casati and Varzi (1999): 39. They note that it fails in some mereologies that admit the existence of 'open' individuals, viz., entities with no boundaries as parts, as well as 'closed' entities that do contain boundary parts; but they, like Simons, are hostile to the very distinction (1999: 79).

${ }^{10}$ Donnelly (2011): 230.

${ }^{11}$ Smith (2009). 
restrict their understanding to the familiar material objects of ordinary experience - precisely because they do not consider atypical cases when framing their formal axioms or foundational principles.

With this background in mind, we can see that an appeal to WSP is one of the weapons the corruptionist will use against the survivalist. For if, as survivalists claim, both the soul and the person survive physical death - the separation of the soul from the body - the only credible relation they can have in the afterlife is that of part to whole. The person survives, but only because he still has a proper part - the single proper part that is his soul. So, for example, Stump writes of Aquinas's position: 'a human being can exist when he is composed of nothing more than one of his metaphysical constituents, namely his form or soul. For Aquinas, in the case of human beings, the persistence of one metaphysical part of the whole thing is sufficient for the existence of that thing. ${ }^{12}$ Again, Hershenov and Koch-Hershenov defend the view that it is metaphysically possible for us to survive the loss of our body while remaining distinct from but intimately connected to our soul whose only ontological status becomes that of being our only proper part. ${ }^{13}$ I have expressed the same position, framed in terms of constitution (as does Stump). ${ }^{14}$

Here is the response of the leading corruptionist. Patrick Toner first claims that WSP 'is a deeply intuitive principle'. Secondly, he claims that 'St Thomas himself endorsed it, or something very much like it. ${ }^{15}$ By 'something very much like it', Toner means that Aquinas may not have had the disjointness aspect of WSP in mind, but he at least thought that any object with a proper part must have at least one other non-identical proper part, which is sufficient to make the anti-survivalist point. Clearly there is both an exegetical issue and a philosophical issue, though consideration of the former naturally leads to the latter. Since the authority of St Thomas is invoked on both sides, and getting clear on his view takes us to some of the metaphysical questions at hand, I will proceed by first examining Aquinas's position, discussing at the same time the philosophical matters it raises. I will then leave Aquinas to one side and examine both the corruptionist's anti-survivalist objections and the positive survivalist case.

\footnotetext{
${ }^{12}$ Stump (2003): 53.

${ }^{13}$ Hershenov and Koch-Hershenov (2006): 440.

14 Oderberg (2005); (2007).

15 Toner (2009b): 456 for both quotations.
} 


\section{WAS AQUINAS A DEFENDER OF WEAK SUPPLEMENTATION?}

The textual evidence does suggest that St Thomas believed no object could have a single proper part, but it is not clear that he intended the principle to apply equally to the extra-mundane case of the separated soul. In other words, I read him as falling within the group (laymen and philosophers) Donnelly and Smith both envisage as not having exotic cases in mind when taking it as self-evident that nothing can have a single proper part. So, for example, Toner offers us passages in which Aquinas affirms the need for multiple parts of wholes, but which do not bear the weight he puts on them as enunciations of universal principle. ${ }^{16}$ In one place, Aquinas gives the relation of 'a part ... to another part in order to make up the whole' as an example of union; ${ }^{17}$ in another, he says that 'the parts of these substances are many, because since each whole is composed of many parts, there must be more component parts than composite wholes. ${ }^{18}$ The first quotation involves no more than a passing reference to a typical example of union given along with many others, and can hardly be read as the statement of a universal truth. The second is in the context precisely of a discussion by Aristotle of wholly material substances (in particular plants and non-human animals), and is part of the defence of the thesis that the parts of substances are not themselves substances. In neither context is there any evidence that St Thomas had the full gamut of cases in mind; rather, he was thinking only of material composition, as do most people when they consider the part-whole relation.

Since isolated references such as these achieve little, it is potentially more fruitful to look for a more official-sounding statement expressed in a context where the philosophical underpinnings are apparent. To be sure this is what Toner does, offering us a thesis Aquinas indisputably takes to be a 'first principle of demonstration': 'when it is known what a whole is and what a part is, it is at once recognized that every whole is greater than its part. ${ }^{\prime 19}$ To this Toner adds, on behalf of corruptionism:

16 Toner (2009b): 459 .

${ }^{17}$ Summa Theologica (hereafter ST): I.II q.28 a.1, obj.2, Aquinas (1914): 326. ['pars toti vel alteri parti ad constitutionem totius ...']

${ }^{18}$ Commentary on Aristotle's Metaphysics: Book 7, Lesson 16, n.2, Aquinas (1995): 540 (para. 1632). ['partes esse plurimas harum substantiarum, quia, cum unumquodque totum ex pluribus componatur, oportet plures esse partes componentes quam tota composita.']

${ }^{19}$ ST: I q.2 a.1, obj.2., Aquinas (1920): 20. (My translation is a slight modification of the latter. Of course, by 'greater than its part' St Thomas means 'greater than each of its parts', as Toner also notes; otherwise it would be what is technically known as a 'slam 
'If an object has just one proper part, then the object is no greater or lesser than its part. ${ }^{20}$ This, however, is not an assertion Aquinas makes, but a proposition to which Toner commits Aquinas on philosophical grounds. Why should we (or Aquinas) think an object with a sole proper part is no greater than that part? ${ }^{21}$ We need to look first at what 'greater' may mean. Clearly, if 'greater' has a purely quantitative sense (e.g., spatial or material) Toner's claim won't apply to an immaterial soul sustaining the immaterial existence of a person. But then Aquinas's own principle that the whole is greater than its part will not apply either, and the survivalist ought to accept that principle as a universal truth. So we should accept, as Toner insists, that when St Thomas says 'greater' he does not restrict the meaning to quantitative part-whole relations. Since - at least in the case of substances, including persons - the part subserves the whole and is ontologically dependent on it (as Aquinas, following Aristotle, holds to be the case) 'greater', when it comes to substances, means something like: 'possessed of some quality or characteristic that marks the whole out as ontologically independent and the part as ontologically dependent and subservient to the whole.'

So for the survivalist, the obvious move to make is to point out that the soul is ontologically dependent on the person whose soul it is. Contra Platonism or Cartesianism, the soul is not a complete substance in its own right, however intimately it might be united to a particular body for all of its earthly existence. On the Thomistic view the soul informs the matter that makes up the body of the person. More precisely, the soul informs prime matter, a featureless material substratum, to produce a particular person's body. (That it is prime (or primary) rather than secondary matter the substantial form unites with in producing any substance is a key point to which I will return later.) For Aquinas it would be incoherent to suppose that a given person's soul should be capable - logically - of informing the matter of some other person's body. The soul, then, is wholly derivative from the person, as is the person's matter. The person is logically and ontologically primary, the soul secondary. ${ }^{22}$

dunk' for survivalism.) ['scito enim quid est totum et quid pars, statim scitur quod omne totum maius est sua parte.']

${ }^{20}$ Toner (2009b): 456.

${ }^{21}$ It is not clear to me what Toner's 'or lesser' adds to the argument.

${ }^{22}$ To be sure, Aquinas believes that God creates each human soul (ST I q.90 aa.2-3, Aquinas 1922: 256-9) but this does not leave room for the hypothesis that the soul He created for one person He might have created for another. This is clear enough from 
The soul, being made for the matter of a particular body, tends essentially to union with that matter again (as will occur at the Resurrection) in order to function fully as the soul it is - of a particular person. The person does not tend essentially to union with anything in order to have its full function. After death, the person exists in a diminished, highly reduced state, but that is because she lacks a body, not because she needs to unite with a body. Another way of putting the idea is that a person has the intrinsic tendency to be a hylemorphic compound; the soul, however, has no tendency to be a compound, only to unify with another part so as to constitute a complete person. And as to function and operation, Aquinas could not be clearer: the soul does not think or understand in any way other than that in which the eye sees. 'Man understands through his soul', he writes, just as man sees through his eyes. ${ }^{23}$ This latter point itself should encourage the corruptionist to reconsider what they are committing themselves (and Aquinas) to: for if the soul exists without the person in the afterlife, and yet is still capable of intellectual operation, then on Aquinas's analogy it would be like the existence of an eye that is capable of seeing (in the derivative sense, since it sees in no other) without an organism to which it belongs, and which performs the very primary act of seeing in virtue of which the eye can even be truly said to see in the first place.

The survivalist, then, has a coherent and plausible story to tell about how the post-mortem person is greater than their singleton part - the soul. Yet Toner's response to this way of explaining the distinction between soul and person is to object: 'Saying that the two things differ in their properties doesn't solve the problem [of accounting for their distinctness]: it states it. ${ }^{24}$ To which the survivalist rejoinder ought to be that denying the possibility of a whole greater than its singleton part is just to assume WSP in the first place, which is precisely the principle in dispute! I submit that there is a misunderstanding of the dialectic here. The survivalist's objective is not - or at least should not be - to prove the truth of their position by showing how the person and

ST I q.90 a.4, Aquinas (1922): 259-61, where Aquinas argues that each soul is created at the exact same time that the body to which it is united comes into existence, fitted for that body alone. (How could it be otherwise if it informs the matter of which the body is composed?)

${ }^{23}$ ST I q.75 a.2, ad 2, Aquinas (1922): 8-9. ['Potest igitur dici quod anima intelligit, sicut oculus videt, sed magis proprie dicitur quod homo intelligat per animam.']

${ }^{24}$ Toner (2009b): 457. 
their singleton proper part differ in properties. ${ }^{25}$ The survivalist has independent grounds for believing both soul and person exist, grounds concerned mainly with justice and personal responsibility (issues that await a different discussion), but also purely metaphysical reasons having nothing to do with a difference of properties (such as the analogy with the eye just noted). The question at hand is: if survivalism is true, can the soul and person be distinguished? The corruptionist wonders what could distinguish them, in contrast with the case of there being more than one proper part - where it is clear that the whole must be greater than any of its parts. The survivalist offers various ways in which soul and person differ in their natures, showing that WSP is not the only way of guaranteeing a distinction between whole and part. What the survivalist appeals to is not a concoction of hypotheses about how the soul and person might differ, but claims about how they do and must differ given their essential natures, upon which latter both sides agree. ${ }^{26}$ So, to clarify the dialectic: when it comes to WSP, the survivalist does not and cannot use its mere denial, however justified, to prove that soul and person must exist in the afterlife (pre-Resurrection). The corruptionist, on the other hand, wants

${ }^{25}$ It might be thought the survivalist could do this, since it would involve an uncontroversial appeal to the Indiscernibility of Identicals: if the soul can be shown to have/lack properties the person lacks/has, then of course they must be distinct. But this would not do. Take a more mundane case, where I convince a rather deluded you that Al Gore is not Bill Clinton because Clinton is from Arkansas and Gore is not. Here, we both agree that Bill Clinton and Al Gore exist; it's just a question of working out whether they are the same person. In the survivalism/corruptionism debate, the key issue is precisely whether, in the afterlife, both soul and person exist, or soul only. I cannot prove that both exist by distinguishing them since this would indeed be question begging. But as I note above, this is not the survivalist's argumentative strategy anyway.

${ }^{26}$ It might look as though the corruptionist also appeals to a Leibnizian principle, namely the more controversial Identity of Indiscernibles. Again, this is not quite what is going on. The corruptionist argues that the soul and person in the afterlife are indiscernible, but does not conclude that they must be identical. After all, both sides agree with Aquinas's famous statement, 'I am not my soul' ['anima mea non est ego'] (Commentary on St Paul's First Letter to the Corinthians 15: lec. 2; see <http://josephkenny.joyeurs.com/CDtexts/ SS1Cor.htm\#152> [last accessed 25.7.12]). So the corruptionist concludes not that soul and person must be the same since if they were distinct they would be indiscernible, but that either the soul or the person does not exist at all in the afterlife (as always, qualified by 'before the Resurrection'). Since everyone in this debate agrees that the soul does exist, it must be the person who does not. (Note, in passing, that the passage within which 'anima mea non est ego' occurs is commonly appealed to by the corruptionist as prime evidence that Aquinas is on their side. See, for example, Kenny (1993): 138 and note at 173. I will examine this and all the other relevant texts on another occasion.) 
to use the truth of WSP to argue that corruptionism must be true, since otherwise the person would have to exist with a single proper part. And as part of their defence of WSP, they argue that any object with a single proper part could not be distinguished from that part; so, in the case of soul and person, the person cannot exist if the soul alone does (with no supplementary part). But all sides agree the soul does exist with no supplementary part, following physical death. The survivalist, by showing in a principled way how soul and person would differ in properties if they both existed in the afterlife, blocks the corruptionist move.

Before leaving St Thomas behind (not entirely), I want to close this section with another important text cited by Toner. ${ }^{27}$ The passage from Aristotle on which Aquinas comments is as follows: '[I]f it [sc. something] is a compound [sc. of elements], clearly it will be a compound not of one but of more than one (or else that one will be the thing itself)..${ }^{28}$ Here is St Thomas's gloss:

Therefore, if this something else when found is not an element but is composed of elements, it is evident that it is not composed of one element only but of many; because if it were not composed of many but of only one, it would follow that that element would be the same as the whole; for what is composed of water only is truly water. ${ }^{29}$

Now for Toner's gloss on Aquinas: 'What this quotation seems to tell us is that anything composed of only one thing must be identical with that one thing ... if a thing has only one part, that part must be an improper, rather than a proper part: the whole must be the same as the one part.'30 Immediately, however, there is a wrinkle, for as Toner recognizes, Aquinas's example of water suggests that he had in mind a wholly different idea, namely that if something is composed of only one kind of element, then it must be the same kind of thing as the element. Toner makes two main points to shore up his interpretation. ${ }^{31}$ The first is that 'the reason

${ }^{27}$ Toner (2009b): 458.

${ }^{28}$ Metaphysics VII: 1041b22, Ross (1928). The Greek reads: 'ei de ek stoixeiou, dēlon hoti oux henos alla pleionōn, è ekeino auto estai ...

${ }^{29}$ Aquinas (1995): 552. ['Si ergo istud aliud inventum, non sit elementum, sed sit ex elementis; palam est quia non est ex elemento uno tantum, sed ex pluribus elementis. Quia si non esset ex pluribus, sed ex uno tantum, sequeretur quod esset illud idem elementum totum. Quod enim est ex aqua tantum, est vere aqua.']

${ }^{30}$ Toner (2009b): 458.

${ }^{31} \mathrm{He}$ also makes a third in a note: Toner (2009b): 470, n.21. It is that even if we allow that a whole could be composed of a single part with which it was not numerically 
we find it so obvious that a whole composed of just one element must be the same kind of thing as the element is that we find it obvious that a whole composed of just one part is identical with that part'. I do not see the connexion, since only an equivocation over 'same kind' could generate one. Where Aquinas is clearly talking only about one thing's being made of the same kind of stuff as another, Toner uses this sense first and the second sense - being the same kind/species of thing - immediately following. The reason we find it obvious that something composed of only one kind of stuff must be made of the same kind of stuff as the stuff (tautologically) is itself has nothing to do with the specific identity of the thing and the stuff and everything to do with composition: if it's only got wood as the stuff of which it is made, it is wholly wood, and the same for water or any other stuff. ${ }^{32}$ But if anyone - myself excluded - finds it obvious that an object with a single part must be numerically - and hence specifically - identical to that part, it cannot be because of something to do with the stuff of which they are/it is composed; otherwise, they would have to find it obvious that an object composed of more than one part must be numerically - and hence specifically - identical to all of the parts taken collectively, so long as those parts were themselves all made of the same stuff. Corruptionists should not want to accept that, assuming they allow - as I take it they do - for numerical identity of a whole through mereological change.

The second point is that 'if the compound must be of the same kind of thing as the one element in it, and the human being is composed solely

identical, we would be saddling Aquinas with the 'bizarre' view that two things of the same kind can wholly coincide. I think this point, like the first, trades on an equivocation over 'kind'. The two putatively overlapping things - say, the clay statue and the lump of clay - are indeed of different kinds: one is an artefact, the other is a lump of (let us suppose) naturally occurring matter. Yet both are made of the same kind of stuff, viz. clay. Or one will be an artefact of one kind and the other an artefact of another kind (say, a statue made out of a bicycle): they will be generically identical but specifically distinct. But they will both be made of the same kind of stuff (metal, say). For a watery example, suppose a large puddle of water and the water that composes it. The first is a puddle (a countable object), the second some stuff (non-countable) that composes and wholly overlaps with it. But both are made of water. Moreover, in Oderberg (1996) I give unrelated examples of two objects of the same kind wholly coinciding even in the first sense of 'kind', viz. specific identity; I call such examples 'Leibnizian cases'. So the view Toner labels as bizarre is in fact quite plausible.

${ }^{32}$ This is one reason why the so-called fallacy of composition does not apply universally. 
of her soul, then she's the same kind of thing as her soul. ${ }^{33}$ But this would be absurd, since then the human being would be a proper part of herself which is impossible, or else this would simply mean she was identical to her soul, contrary to Aquinas's view, on which both sides are agreed. Again, however, it is the equivocation on 'same kind' which produces a specious objection. St Thomas's water example shows that he is speaking of compositional identity, not specific identity. So it should be with the soul and the person, and so it is: the person following physical death is made of a single immaterial proper part; from which it follows that just as the part is immaterial, so is the whole.

To conclude this section, I claim that the whilst the corruptionist puts forward an impressive-seeming case to the effect that Aquinas believed in the Weak Supplementation Principle (or something sufficiently similar to make the corruptionist's point), the truth is that the case rests on a combination of misreadings or tendentious interpretations of passages from St Thomas, coupled with references to brief passages that were never meant to be official statements of Aquinas's position on composition. Like most of us, he almost certainly took it as a general truth that wholes require more than one proper part. But he never takes on this specific question in the immediate context of a discussion of post-mortem survival. The survivalist certainly cannot contend that Aquinas anywhere denies WSP. But the survivalist case does not rest on this. A defensive reading of Aquinas that is both plausible and allows space for a view of mereology consistent with survivalism is all that the survivalist should ask from the Angelic Doctor. ${ }^{34}$

\footnotetext{
${ }^{33}$ Toner (2009b): 458-9.
}

${ }^{34} \mathrm{I}$ also would like to note the following interesting passage, brought to my attention by Gyula Klima. In the Commentary on the Sentences, Aquinas writes: 'Otherwise is the opinion of Aristotle, which all moderns follow, that the soul is united to the body as form to matter; whence the soul is a part of human nature, and not human nature itself. And since the essence of the part differs from the essence of the person, as it is said, so the separated soul cannot be called a person: since although, being separate, it is not actually a part, still it has the nature of being [the natural tendency to be] a part' (lib. 3 d. 5 q. 3 a. 2 co.; my translation). ['Alia est opinio Aristotelis quam omnes moderni sequuntur, quod anima unitur corpori sicut forma materiae: unde anima est pars humanae naturae, et non natura quaedam per se: et quia ratio partis contrariatur rationi personae, ut dictum est, ideo anima separata non potest dici persona: quia quamvis separata non sit pars actu, tamen habet naturam ut sit pars.' See <http://www.corpusthomisticum.org/spd3004. html\#92376> (last accessed 27.6.12).] 


\section{SHOULD WE BELIEVE \\ IN THE WEAK SUPPLEMENTATION PRINCIPLE?}

Moving on from the more arcane reaches of Thomistic exegesis, I want to consider WSP in the light of general metaphysical considerations. It is understandable why its supporters speak as though it were a conceptual truth of parthood that wholes must have more than one part. ${ }^{35}$ For material substances and the bits that compose them are the typical phenomena we have in mind when thinking about parts. It is the perceptually familiar that sets the framework within which we think about most of the core metaphysical concepts. This is why efficient causation is the model according to which most philosophers and layfolk think about causation in general, and why it is much easier, even for a highly trained philosopher, to ponder the concrete rather than the abstract. More specifically, a certain kind of spatial thinking dominates our grasp of parthood - the idea, that is, of a part as spatially smaller than the whole. If a material whole has a certain spatial extent, then any one of its parts must have a smaller extent. And if it is smaller, there must be at least one other non-overlapping part to make up the remainder. It is this idea of a remainder to which Koslicki appeals to defend the intuitive plausibility of WSP. ${ }^{36}$ Although she does not explicitly put this in a spatial context, I think Donnelly is right to suggest that spatial thinking - in

Again, a quick first reading would suggest St Thomas is saying quite clearly that the separated soul is not a part of anything, so there is no whole (the person) in existence in the pre-Resurrection afterlife. What is really going on here, I submit, is nothing more than Aquinas's usual denial that the soul is the person (anima mea non est ego). The context ('otherwise is the opinion ...') is Aquinas's rejection of Platonic dualism and any metaphysic that has the person as an accidental unity of body and soul, with the soul a complete substance in its own right and the essence of the person being given wholly by the soul. As for 'it is not actually a part ..., I read this as meaning not that in the afterlife the soul is a part of nothing; rather, that it is not doing what it actually does on earth, namely compose with another part (matter) to constitute the complete person. In the afterlife it still has the natural tendency to unite with a body, which is why it is an incomplete substance: the soul's entire reason for being, as it were, is to inform matter. It can exist on its own, i.e. apart from matter, but neither it, nor the person it constitutes in the afterlife, functions perfectly (in full accordance with their natures). The soul lacks the performance of those functions, such as sensible memory, that rely on the body, and the person, in virtue of this, also lacks those functions. Further, the person cannot exercise any bodily functions, including those the soul never could do - walk, embrace, eat, and so on.

${ }^{35}$ From now on I will usually omit the adjective 'proper' when speaking of proper parts, and speak explicitly of improper parts when referring to the latter.

${ }^{36}$ Koslicki (2008): 168. 
the sense of parts as spatially smaller than their wholes - lies behind the remainder idea. She comments: 'But once we allow that a whole can have a proper part which is spatially co-extensive with it, then I think that (WSP) loses its appeal. ${ }^{37}$

Consider, then, three closely related examples of objects that seem to have a single part spatially co-extensive with the whole. One is the notorious statue and the lump of clay, which Koslicki discusses at great length to motivate her case. Another is proposed by a survivalist: a tree that has all its branches cut off until all that is left is its trunk. ${ }^{38}$ A third, rather gruesome example that I have proposed in the past, is a person whose entire body is amputated below the neck, with their head maintained by futuristic technology. ${ }^{39}$ All of these cases, I submit, violate WSP because they involve a whole's possessing a part that is not disjoint from any other part of the whole. The corruptionist should accept this way of interpreting the cases, and so cannot appeal to WSP as a universal truth that immediately blocks the survivalist account of the afterlife.

Consider the statue and clay. It takes, in myview, a leap of metaphysical thinking too far to suggest that these are not distinct objects with distinct persistence conditions. ${ }^{40}$ If they are distinct, the question is what relation they have to each other apart from spatial coincidence. It is not enough to say that the lump's existence, assuming the lump to be appropriately configured, is sufficient for the existence of the statue, true though it be. The question is what relation holds between the statue and the lump, not between the statue's existence and that of the lump. Moreover, many objects can spatially coincide without the existence of one being sufficient for the existence of the other: two beams of light, emanating from distinct sources but perfectly overlapping, will not be such that the existence of one is sufficient for the existence of the other. ${ }^{41}$ It is no surprise that so many metaphysicians adopt a 'constitution' view of the matter, according to which the lump constitutes the statue over the period of the statue's existence. In other words, if you think - as you should - that the statue and lump are distinct objects, then what other relation could there be between them during the time of their coincidence

${ }^{37}$ Donnelly (2011): 230.

${ }^{38}$ Hershenov and Koch-Hershenov (2006).

${ }^{39}$ Oderberg (2005); (2007): ch.10.

${ }^{40}$ The literature on this is extensive. For an overview, see Rea (1997). For a well-known debate on the topic, see Burke (1992), Lowe (1995), Burke (1997).

${ }^{41}$ See further Oderberg (1996). 
than that of part to whole? The term 'constitution' as used in this context is clearly a philosophical term of art but should not mislead anyone into thinking it is not a mereological notion all the same.

The easiest way to think of a part that constitutes a whole is as either the single or the largest proper part of a thing: ${ }^{42}$ single if the whole has no other proper parts because the single part is mereologically simple or the transitivity of proper parthood fails; largest if the whole has more than one proper part. 'Largest' need not be understood spatially. For example, suppose the soul were mereologically complex (an unorthodox view among traditional believers in immortality, but leave that aside). In the afterlife it would still constitute the person, being the person's largest proper part, but where 'largest' would be understood non-spatially, for instance in terms of asymmetric relations of entailment between the powers of the soul and the powers of any of its parts.

So if the constitution view is correct, there are parts that constitute and parts that do not. The ones that do not nevertheless compose, partially or completely, the whole. Moreover, there is no sharp division between compositional parts and constitutive parts, or better, between parts playing a compositional role and parts playing a constitutive role. Suppose, for instance, that our statue constituted wholly by a lump of clay nevertheless has some broken parts, and that these are repaired by a few lumps of plaster. The lump of clay still exists, we should say, but it no longer plays a constitutive role: it now plays a compositional role, composing with the lumps of plaster to produce the statue. Conversely, suppose the lumps of plaster fall off: now the lump of clay has reverted to its constitutive role and no longer plays a compositional role in the sense I mean. The survivalist takes this as an analogy for what happens at physical death: the soul, which previously played a compositional role in union with matter to produce the soul-body compound that is the person, now plays a purely constitutive role as the person's single proper part. This way of looking at constitution should dispel worries that there is something, as it were, ontologically 'spooky' about constitutive parthood. A constitutive part - one playing a constitutive role - can also be, or have been, a compositional part in the usual sense of 'part' at some other point in the history of the whole.

\footnotetext{
${ }^{42}$ Note: this definition is not supposed to prove that constitution occurs. Rather, if you have established on independent metaphysical grounds that constitution occurs, you can understand the part that does the constituting in the way defined above.
} 
Next, although one might not regard constitution as a weird relation, still one might think it entails the problematic result that distinct objects can share all their parts. Now, as Toner recognizes, ${ }^{43}$ this does not apply to the survivalist scenario, since the soul does not have parts in the first place, though he uses the point to cast overall doubt on constitution. Moreover, even if the soul has parts (as I noted, a heterodox view in this debate), soul and person will not share all their parts, since the person will have the soul as a part but the soul will not be a part - proper part, remember - of itself. Still, it is worth noting that the statue and lump of clay should not be regarded as sharing all their parts, even leaving aside the obvious fact that they don't both have the lump as a proper part. ${ }^{44}$ The statue has a nose and arms, the lump does not, albeit some of its parts are nose- and arm-shaped. If I squash the statue's nose I have destroyed one of its parts, and probably reduced its artistic and monetary value at the same time. But I have not also destroyed a part of the lump: the lump is still all there, but the statue is not.

Still, classical mereology recognizes both a weak and a strong version of supplementation. The Strong Supplementation Principle says that if $\mathrm{x}$ is not a part of $\mathrm{y}$, then $\mathrm{x}$ has a part (proper or improper) that is disjoint from $\mathrm{y}^{45}$ The SSP rules out two objects' sharing all of their parts, and with the anti-symmetry of parthood (if $\mathrm{x}$ is part of $\mathrm{y}$ and $\mathrm{y}$ is part of $\mathrm{x}$, then $\mathrm{x}=\mathrm{y}$ ) entails WSP. ${ }^{46}$ On a spatial reading of parthood, SSP is highly plausible: if my left arm is part of me but I am not part of my left arm, there, there will be parts of me beyond the spatial boundaries of, i.e.

${ }^{43}$ Toner (2009b): 458 .

${ }^{44}$ Koslicki denies it (2008: 178, n.15), as does Baker (2000) although the latter makes a distinction between having parts derivatively and having them non-derivatively. She claims that the lump and statue do share all their parts if we include both derivative and non-derivative possession, but stresses that this is a significant metaphysical difference which requires the qualification of a phrase like ' $x$ has part P' if we are to understand what is going on. I am not persuaded by the distinction, at least when it comes to some cases of possession of parts: to say that the lump has a nose derivatively is merely to say that it stands in the constitution relation to an object (the statue) that has a nose nonderivatively. It is hard to see what is gained by calling this the possession of a part, and the thought is counter-intuitive: as noted above, if I squash the statue's nose I have truly destroyed one of its parts, but have I also truly destroyed a part of the lump? Hardly: the lump is all there; it has not been mutilated, only reconfigured; but the statue really has been mutilated. (Thomson $(1983 ; 1998)$ by contrast, does think the statue and clay share all their parts.)

${ }^{45}$ Simons (1987): 29.

${ }^{46}$ Donnelly (2011): 237. 
disjoint from, my left arm. But there are more ways not to share parts than spatial ways: in the case of coincident objects like the statue and the lump, SSP is false: the statue is not part of the lump, but it has no parts that do not overlap any part of the lump. Yet the statue still has parts (like a nose) the lump lacks. So if we deny WSP, and retain anti-symmetry (as I think we should), we must deny SSP; but we do not thereby affirm that distinct objects can share all their parts.

Furthermore, even if we replace SSP with a broader non-sharing principle - if $\mathrm{x}$ is distinct from $\mathrm{y}$ then either $\mathrm{x}$ has a part that is not part of $y$ or vice versa - we still do not capture all there is to the distinctness of coincident objects. If we suppose that the statue and lump do share all their parts, they are still distinguished by virtue of their different persistence conditions and modal properties: the lump came into existence before the statue and can persist beyond the destruction of the statue, and so on. A more difficult case is the tree reduced to its trunk. We cannot really say the tree and trunk come into existence at different times, nor that they could have, nor that one could outlast the other. ${ }^{47}$ But the trunk was once spatially included within the tree and now is not. The tree can survive having, say, ninety percent of its matter cut away, but the trunk cannot. The tree can, say, grow fruit but the trunk cannot, albeit the trunk supports the growth of new fruit (as do the roots, but they do not grow fruit either). Again, as I noted earlier, the point is not to prove that there are distinct objects here, a tree and a trunk: rather, if there are distinct objects, they are capable of being distinguished - and this even if we suppose they share all of their parts. ${ }^{48}$

My claim is that the statue/clay, tree/branch, and head/person cases all violate WSP, and in a way that is far less exotic than the timetravelling brick albeit - in the second and third cases - involving some subtle considerations going to the root of hylemorphism. First, the

${ }^{47}$ Killing the tree cannot leave the trunk if, following Aristotle, we do not regard the dead wood that was the trunk as still a trunk - rather than just a trunk-shaped lump of dead wood - after the tree has died. On Aristotle's 'homonymy principle', see The Parts of Animals 640b35-641a5 (Ross 1912).

${ }^{48}$ Toner (2009b: 461) seems to misinterpret the mereological principle in play here. He claims that he can accept WSP while also accepting that two distinct material objects may share all their parts 'at some level of decomposition'. But levels of decomposition do not come into it. The worry about sharing of parts is not that the statue and lump, say, have all the same atoms. The worry is that if they have all of their parts in common, at all levels of decomposition, they cannot be distinct. I have argued against this, but it is important to note what the source of the concern is. 
statue and clay. The lump of clay is wholly co-extensive with the statue. Although, as I have argued, they do not share all their parts, there is no proper part of the statue that is disjoint from the lump: the statue's nose, for instance, although not a part of the lump, shares some of the clay belonging to the lump. Now, Donnelly (2011) argues in detail that there are alternative systems of mereology that do not have WSP as an axiom yet give the parthood relation sufficient logical properties to distinguish it from other strict partial orderings (such as 'strictly less than'; all such orderings being asymmetric and transitive). In particular, she argues that in one alternative system, if we allow the statue and lump to be proper parts of each other (denying anti-symmetry), then there is no supplementation principle that applies. Only if one is not part of the other does an analogue of WSP come into play. Whilst I accept Donnelly's overall point that WSP does not have to figure as an axiom of every formal mereology capable of distinguishing parthood from other strict partial orderings, and that WSP is not self-evident anyway (except where proper parthood is understood solely in terms of smaller spatial extent), I find it a high price to pay that we should hold the statue to be a part of the lump. Rather, it may be that the nature of parthood cannot adequately be captured in a formal system. More precisely, it may be that all we can say about the agreed logical properties of parthood is that they make it a strict partial ordering, but in order to differentiate it from other strict partial orderings we have to say something purely metaphysical, not logical or formal.

To put some flesh on this idea, we need to examine a number of truths about the various relations between parts - all in the neighbourhood of WSP - that strongly suggest there is no universal principle of supplementation, let alone one that can be captured in any kind of formalization. Taken as a universal truth about parthood, WSP is false: the statue and clay, the tree and its trunk, the bodiless head and the person whose head it is, all violate WSP. On the other hand, there is something about the tree/trunk and head/person cases - and, I would add, the survivalist scenario - that requires, as it were, respect for the spirit of WSP though they violate its letter. Neither the tree reduced (constitutively) to its trunk, nor of course the person reduced to his head, function normally. Both are in a highly impaired state, the removal of which requires the reinstatement of mereologically non-overlapping parts: the head needs its body for the person to function normally, and the trunk needs branches and leaves for the tree it constitutes to function normally. 
Similarly, as both sides of the survivalism/corruptionism debate agree, the soul needs a body for the person to function in his proper way, as a mereological compound. The soul has an intrinsic, essential tendency to unite with matter and is unable to carry out the functions it subserves that also require matter, such as sensation and of course the maintenance of bodily functions. Put this way, what we can say about the disembodied soul is weaker than WSP, which requires an actually existing disjoint part with which the soul must compose if the soul is to be a part of a whole at all. Though weaker, however, it is a far deeper metaphysical insight about the nature of certain kinds of part (those that belong to animate beings) that cannot be captured by a formal principle. This might be discomfiting for mereology as a purely formal system, but it means nothing untoward, and is indeed rich material, for mereology conceived as the metaphysical study of parts and wholes.

The corruptionist might, nevertheless, look for a principle weaker than WSP that is still formalizable and sufficient to undercut survivalism. Whether intentionally or not, Toner hints at this strategy when, in discussing the tree/trunk case, he insists that 'anything with a proper part must have at least two disjoint proper parts', going on to explain that 'both the tree and the trunk do have at least two disjoint proper parts (the tree has lots of molecules as parts, and so does the trunk).49 But this is a misstatement of WSP and hence the explanation is not to the point. The principle that anything with a proper part must have at least two disjoint proper parts is what Cody Gilmore calls 'quasi-supplementation': if $\mathrm{x}$ is a proper part of $\mathrm{y}$, then there are $\mathrm{z}$ and $\mathrm{w}$ such that $\mathrm{z}$ and $\mathrm{w}$ are disjoint proper parts of $\mathrm{y}^{50} \mathrm{QSP}$ does not require that every proper part of a whole must itself have a disjoint proper part, only that any whole with a proper part must have disjoint proper parts. Clearly the statue, the tree, and the bodiless person all have multiple disjoint proper parts, but neither the lump of clay, nor the trunk, nor the head have any proper parts disjoint with them. The corruptionist might wish to say ${ }^{51}$ that QSP neatly cleaves these cases from the survivalist one because the former all obey QSP but the latter does not: the post-mortem, pre-Resurrection person does not have more than one proper part. Like WSP, however, QSP does not have intuitive plausibility outside a specific context, that of

\footnotetext{
${ }^{49}$ Toner (2009b): 461.

${ }^{50}$ Gilmore (2009): 119, n.45. Cited also by Donnelly (2011): 231.

${ }^{51}$ I emphasize that I am not suggesting Toner would wish to say this.
} 
material objects with parthood understood as smaller spatial inclusion. Gilmore claims that QSP does justice to the intuition Simons appeals to in defence of WSP, namely that 'if a universe is complex (i.e. has proper parts at all), then at least two of these parts will be disjoint. ${ }^{52}$ Perhaps, if the intuition is understood to be about mereological complexity in general rather than mereological composition in particular, and if our model of complexity is material. ${ }^{53}$ What I mean by this is that to say the universe or something in it is complex is only to say that it has more than one part; but to say something more, specifically about how the parts fit together, is to speak about composition. It is hard to see how a complex universe can be consistent with everything's overlapping everything else, as Simons points out. So in the material world, thinking about the spatial chunks that are typically smaller in extent than their wholes, we should expect QSP to hold. There is no reason, however, to expect this to be the case with immaterial objects and their parts: hence, to suppose that QSP excludes the survivalist scenario is not to justify anything, only to note the difference between it and the material analogues.

I now want to raise a more important point, to the effect that WSP itself, though we might plausibly think of it as a principle of composition rather than (like QSP) a principle of complexity, does not say all that needs to be said about composition in this context, and what remains to be said cannot be formalized. Toner has a further objection to Hershenov and Koch-Hershenov's tree/trunk example, namely that their interpretation of it is incompatible with the proper hylemorphic account of the case, one with which hylemorphists on both sides should agree. If the tree and trunk do both exist and coincide spatio-temporally, the tree does have a part the trunk lacks, namely a substantial form (the classical version of Koslicki's 'formal part'). The trunk, being a material spatial part of the tree, is not a substance in its own right, following Aristotle. Like a person's arm or big toe, such a part is truly informed by the substantial form of the whole, but it does not have its own substantial form since that would make it a substance in its own right - contra its

${ }^{52}$ Simons (1987): 27.

${ }^{53}$ And if we take what Simons thinks is a truth about the universe to be a truth about the objects in it as well. Classical extensional mereology, taking parthood to be unrestrictedly transitive, treats claims about things in the universe and their parts to be claims about parts of the universe and vice versa. I let pass this dubious way of looking at the universe and its denizens, as well as putting aside the issue of transitivity, and simply take QSP (and WSP) to be a claim about anything that is complex. 
ontological dependence on the whole. Hence, for Toner, 'the tree/trunk example does not help motivate the rejection of WSP. ${ }^{54}$

Although he does not elaborate, I take it that Toner holds the substantial form of the tree to be a part that is disjoint from the trunk, thus verifying WSP in this case. The problem, though, is that on the classical hylemorphic view the tree is decidedly not a compound of trunk and substantial form. Even if one wished to distinguish between the tree with all its branches and leaves on the one hand, and the lump of plant matter (cellulose, etc.) constituting it on the other (doubtful at best, but let's assume it), the tree would not be a compound of substantial form and that lump. Rather, what the substantial form of any material substance unites with and informs is the underlying prime matter from which that substance, suitably informed, arises. If it were otherwise, the hylemorphist would be committed to the view that the lump of plant matter - secondary matter, for Aristotelians - gets its properties from something other than its substantial form. In other words, the properties of the trunk, wood, branches, bark, leaves, flowers, fruit, and so on, would have nothing to do with the form of the tree and everything to do with something else - if not another substantial form in addition to the tree's form, thus violating the unicity of substantial form (the impossibility of multiple substantial forms in the same substance; see the remarks above), then some other collection of accidental forms that impart to the plant matter its own independent reality and characteristics before (logically before) the substantial form has done any work at all. And with that, substantial forms should be dispensed with as idle explanatory wheels.

To avoid this anti-hylemorphic destination, we must insist that substantial form never unites with secondary matter: it only unites with an underlying primary stuff in order to produce the finished substance. But this is something that is not captured by WSP, nor can it be formalized. WSP requires only that every part of a whole have a disjoint part: it says nothing about how the disjoint parts fit together, how they function in relation to each other. Since the model for WSP is materially filled spatial regions smaller than the whole, we already have a grasp of the metaphysic behind the principle: these regions filled with matter lie within the area or volume of the whole; we can appeal to topology and various kinds of material connexion to spell out, if only incompletely, the way the material parts fit together. But this is not the right model

\footnotetext{
${ }^{54}$ Toner (2009b): 461.
} 
for the form/matter relation: the informing of matter is a different and distinctive kind of relation, one involving concepts of actuality and determinacy. The parts are not themselves bits of anything; rather, they are metaphysical principles (in the sense of originating sources) from which the material substance arises. The substantial form of the tree might be disjoint from the trunk, but it is not something that composes with the trunk; it composes only with prime matter. So to say that WSP is verified in the case of the tree/trunk is to apply a material model of composition to another kind of composition altogether, and to mix levels of parts in the process. Since the form of the tree does not compose with the trunk, its disjointness from the trunk is not something deriving its reality from the truth of WSP, which is a compositional principle about parts of the same level, and material ones at that. The disjointness of the form of the tree and the trunk is something that falls out of a general theory of form/matter composition, with the trunk as secondary matter and the form of the tree as an immaterial part - a universal - that composes with underlying prime matter, the union of which results in secondary matter - the trunk, if the tree is reduced to this, and also the roots, leaves, branches, and so on if the tree is in its complete state..$^{55}$

The upshot of this rather abstract digression is that even if the tree has a substantial form disjoint from the trunk, this has nothing to do with WSP. The trunk still lacks a disjoint part in the sense in which WSP is supposed to apply. Similarly for the person and their bodiless head: the hylemorphist grants that the person has a substantial form - their soul - but this does not verify WSP either, since the full compositional story is that for all the understandably loose talk of man as a union of soul and body, souls do not compose with bodies. Bodies are secondary matter - the result of the soul's union with primary matter. The body has no life of its own, no identity save as the body of this particular human being: to speak of the soul's literally informing a body is, quite simply, to double-count the soul's function in the compound or else to deny that a substance - in this case, a human being - has exactly one substantial form. In which case the bodiless head does still falsify WSP inasmuch as

${ }^{55}$ Koslicki's approach to form, interpreting it as structure, is more congenial to the idea that the form of the tree, for example, is a disjoint part of any lump of matter that composes the tree at some time. This is because she understands form as structure, and the content that structure configures is, for her, what a classical Aristotelian calls secondary matter. In my view, however, there are serious problems with this new interpretation of form as structure: see Oderberg (forthcoming). 
WSP offers a principle of composition that does not apply to these kinds of scenario: there is no appropriate disjoint part to be the supplement of the trunk or the head. In the statue/clay case, moreover, there is not even a substantial form to appeal to in the first place, since artefacts are not substances: they are constituted by substances - a single lump of clay, in the case under discussion - but are themselves ontologically dependent entities (dependent on an 'artworld', as is sometimes said, or on minds that impose functions or purposes on the artefacts). ${ }^{56}$ And even if we do not say that WSP is falsified in such cases, rather than that it does not apply, the result is the same: WSP is not a universal truth about parts and wholes.

\section{CONCLUSION}

I have argued that there is no persuasive case to the effect that Aquinas believed in the Weak Supplementation Principle, so the corruptionist cannot appeal to this agreed authority in support of their case. For the survivalist, it would be convenient if a case could be made that Aquinas clearly believed WSP to be false. For that matter, it would be highly agreeable for either side if it could be shown he clearly asserted their position. But matters are more complicated than that. I doubt that Aquinas ever gave WSP the sort of consideration contemporary mereologists do, let alone applied it deliberately to the question of post-mortem survival. The more general, and important, question of whether Aquinas believed in survivalism or corruptionism is similarly a complex exegetical matter with no neat answer. My view is that he was a survivalist, but this must await another occasion.

\footnotetext{
${ }^{56}$ In fact the proper account of artefacts is a far more complex affair than I indicate here. In Oderberg (2007): ch.7 I argue that at least some artefacts - among which I count the typical philosopher's statue - should be thought of as identical to an accidental unity, to use the Aristotelian term, consisting of a substance and one or more accidental forms. So the statue is a lump of clay plus whatever accidents modify that lump to have a certain shape, texture, and various other qualities. This view does not prevent the lump from constituting the statue, however, since constitution is not identity in the sense in which the constitution view employs the term. So we can still properly say that the statue is indeed constituted by a lump of clay, yet is identical not to the lump itself, but to the plurality consisting of (identical to) the lump that constitutes the statue plus the accidents that modify the lump. Still, this account does not verify WSP. The accidents are not parts of the statue, although the constituting lump is, along with the smaller parts such as arms and nose that result from the accidents' configuring the lump; so there is no question of disjoint supplements.
} 
The mereological issues at play in the survivalism/corruptionism debate also require careful analysis given the hylemorphic assumptions of both sides. For a non-hylemorphist, the cases discussed above should be seen as clear violations of WSP. But the hylemorphist should agree as long as they are attentive to how the form/matter union needs to be understood. One does not have to appeal to time-travelling bricks or other exotica of dubious plausibility to make a case against WSP. Given this, the soul/person case can be put in its proper context: it is a highly exotic case given mundane mereological thinking, but WSP's truth does not stand or fall with it. We can already cast doubt on WSP before looking beyond the material world, albeit we have to think of parthood in a broader way than is usually done outside metaphysics. With this in place, we can free the survivalist position from being shackled to principles that do not themselves stand up to detailed scrutiny.

\section{BIBLIOGRAPHY}

Aquinas, Thomas. 1914. The 'Summa Theologica' of St. Thomas Aquinas, Literally Translated by Fathers of the English Dominican Province, vol. 6 (London: R. and T. Washbourne, Ltd.)

Aquinas, Thomas. 1920. The 'Summa Theologica' of St. Thomas Aquinas, Literally Translated by Fathers of the English Dominican Province, vol. 1 (London: Burns Oates and Washbourne Ltd.)

Aquinas, Thomas. 1922. The 'Summa Theologica' of St. Thomas Aquinas, Literally Translated by Fathers of the English Dominican Province, vol. 4 (London: Burns Oates and Washbourne Ltd.)

Aquinas, Thomas. 1995. Commentary on Aristotle's Metaphysics, trans. J.P. Rowan (Notre Dame, IN: Dumb Ox Books)

Baker, Lynne Rudder. 2000. Persons and Bodies: A Constitution View (Cambridge: Cambridge University Press)

Brown, Christopher M. 2005. Aquinas and the Ship of Theseus (London: Continuum)

Burke, Michael. 1992. 'Copper Statues and Pieces of Copper: A Challenge to the Standard Account', Analysis, 52: 12-17

Burke, Michael. 1997. 'Coinciding Objects: Reply to Lowe and Denkel', Analysis, 57: 11-18

Davies, Brian. 1992. The Thought of Thomas Aquinas (Oxford: Clarendon Press) Donnelly, Maureen. 2011. 'Using Mereological Principles to Support Metaphysics', The Philosophical Quarterly, 61: 225-46 
Effingham, Nick, and Jon Robson. 2007. 'A Mereological Challenge to Endurantism', Australasian Journal of Philosophy, 85: 633-40

Gilmore, Cody. 2009. 'Why Parthood Might be a Four-Place Relation, and How it Behaves if it is', in L. Honnefelder, E. Runggaldier, and B. Shick (eds), Unity and Time in Metaphysics (Berlin: De Gruyter), pp. 83-133

Hershenov, David B. 2008. 'A Hylomorphic Account of Thought Experiments Concerning Personal Identity', American Catholic Philosophical Quarterly, 82: 481-502

Hershenov, David B., and Rose Koch-Hershenov. 2006. 'Personal Identity and Purgatory', Religious Studies, 42: 439-51

Kenny, Anthony. 1993. Aquinas on Mind (London: Routledge)

Koslicki, Kathrin. 2008. The Structure of Objects (New York: Oxford University Press)

Lowe, E.J. 1995. 'Coinciding Objects: In Defence of the "Standard Account", Analysis, 55: 171-8

Oderberg, David S. 1996. 'Coincidence Under a Sortal', The Philosophical Review, 105: 145-71

Oderberg, David S. 2005. 'Hylemorphic Dualism', in E.F. Paul, F.D. Miller, and J. Paul (eds), Personal Identity (Cambridge: Cambridge University Press), pp. 70-99

Oderberg, David S. 2007. Real Essentialism (London: Routledge)

Oderberg, David S. (forthcoming). 'Is Form Structure?'

Pasnau, Robert. 1992. Thomas Aquinas on Human Nature (Cambridge: Cambridge University Press)

Rea, Michael C. (ed.). 1997. Material Constitution: A Reader (Lanham, MD: Rowman and Littlefield)

Ross, W.D. (ed.). 1928. The Works of Aristotle Translated into English, vol. 8, 2nd ed. (Oxford: Clarendon Press)

Simons, Peter. 1987. Parts: A Study in Ontology (Oxford: Clarendon Press)

Smith, Donald. 2009. 'Mereology Without Weak Supplementation', Australasian Journal of Philosophy, 87: 505-11

Smith, J.A., and W.D. Ross (eds). 1912. The Works of Aristotle Translated into English, vol. 5 (Oxford: Clarendon Press)

Stump, Eleonore. 2003. Aquinas (London: Routledge)

Stump, Eleonore. 2006. 'Resurrection, Reassembly, and Reconstitution: Aquinas on the Soul', in B. Niederbacher and E. Runggaldier (eds), Die Menschliche Seele: Brauchen wir den Dualismus? [The Human Soul: Do We Need Dualism?] (Frankfurt: Ontos Verlag), pp. 151-71

Thomson, Judith Jarvis. 1983. 'Parthood and Identity Across Time', The Journal of Philosophy, 80: 201-20

Thomson, Judith Jarvis. 1998. 'The Statue and the Clay', Nous, 32: 149-73 
Toner, Patrick. 2009a. 'Personhood and Death in St. Thomas Aquinas', History of Philosophy Quarterly, 26: 121-38

Toner, Patrick. 2009b. 'On Hylemorphism and Personal Identity', European Journal of Philosophy, 19: 454-73

Toner, Patrick. 2010. 'St. Thomas Aquinas on Death and the Separated Soul', Pacific Philosophical Quarterly, 91: 587-99

Toner, Patrick. 2012. 'St. Thomas Aquinas on Punishing Souls', International Journal for the Philosophy of Religion, 71: 103-16 